(1) しと古鎌氏なに多伝つ 東たに写倉のさ諸々来系漢

大 1 . 賢十経泻祘れ本本た系訳は

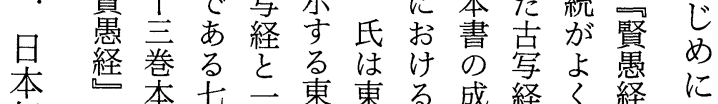

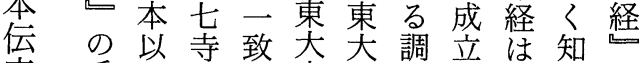

来系外蔵守寺巻を大らは

口統の本る本本品考半机高

賢に中、点はが次察が、麗

愚つ国金落十の娄十い版

経てい剛多わ゙六異る屯ず公

に巻け蔵。か本ので本も話

に数る本よな盗研必で士話

い中賢西て料る究須品巻光

て心愚方本に主福写題本元

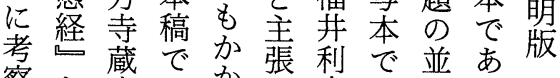

察々蔵でか張梨で並る公

し旦の平わる郎万方が究

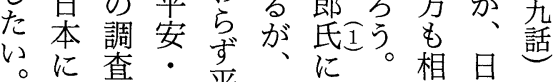

伝真鎌晏福よす違本の

は 印

度

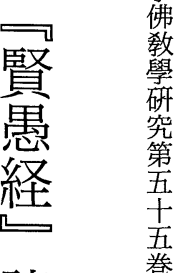

諸第

本号

0) 平

調年第

巻年

す年五ま（2)東十東平もそ鎌るす

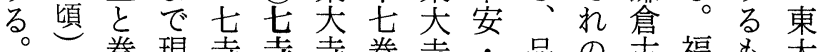

巻現寺寺寺巻寺・品の克福も大

西写年存本本本の本鎌名及写算の寺

方で一すは、とど\|倉な経氏の本

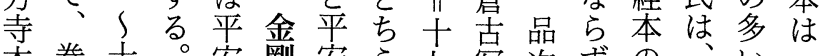

本巻十。安剛安ら七写次ず、の巻中下

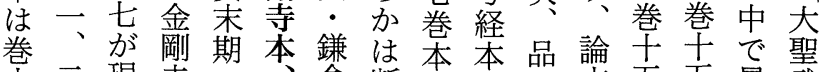

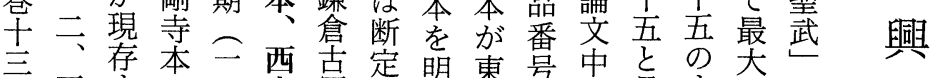

ま五劣は方写で確大果の品すのと

で、る鎌苉寺経き確大寺一そ名べ手も

し六西倉年本絮な系本致の品が称

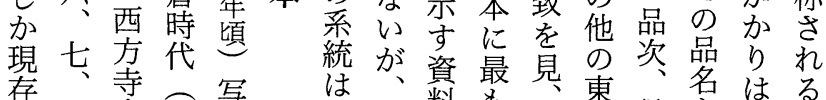

津

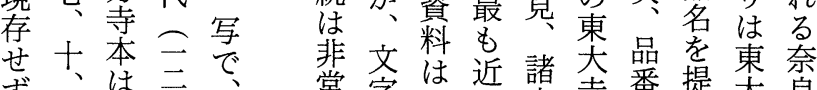

ず、采竞字は近諸寺番提莫良

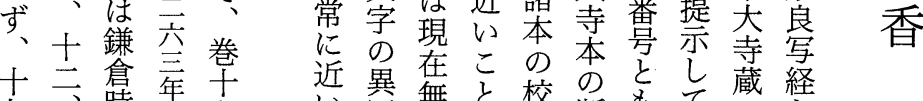

題

に

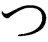

(v)

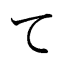

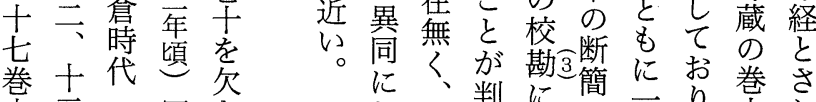

本三三写き

とが二で巻

断現云空

定存一巻七

お士明よに致り、机織

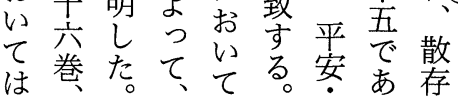




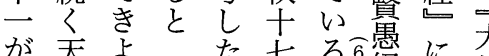

賢尔平う第記巻る。苜経に関旦

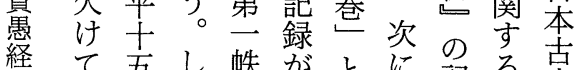

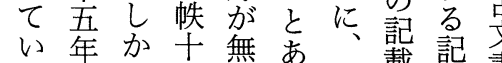

殐た六し巻いる天整述畫可

の五第第同が平あをに文

調で云第云同、十古見掲書

品な六帙六公こ年三と載接

題加巻巻䏴に吾帙天れけ

に。第の十平たる

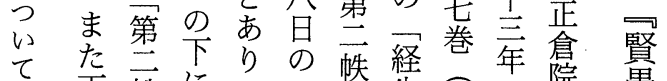

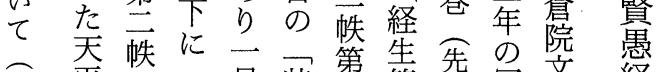

興 平券已見装第等先写紊経

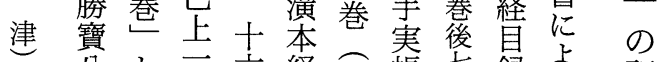

公年巻巻経巻帳巻録っ 記

奉巻机にを判になる゙賢

干第に断よ書三うて显
十続でる写帙て賢経

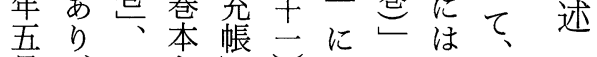

じ寺き查本

系本る而本々は

(3)はのは 統・記二も出じ本き で西両録分に寺系のな 交者に署平本統校い

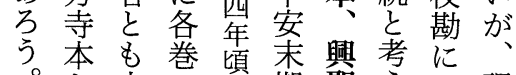
と十の期聖杂現 云始は写寺てり存 致巻め実の本よ異守 す本の見石的読る るで品し山等巻 こあ名て寺架に とりがい蔵拈 か、見な本泟け 亭調芳が二 致調 山六六专 寺品の調六 本次調查年 、が巻報䔛品 興七品告出の

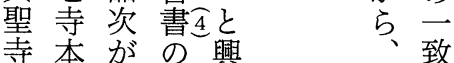
本. 判法哠祀咅 同金断量寺蔵 厹

と慧 (2) 述れま七六ら (1) な琳二こはのた巻巻れ経経

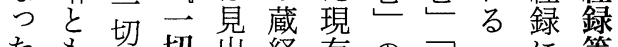
たも切切出経存の干等

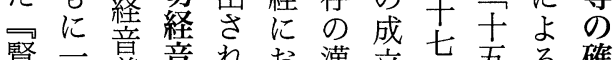

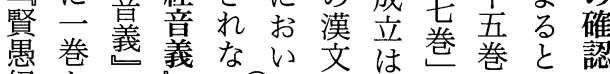

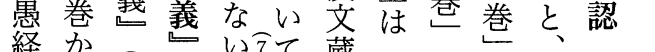

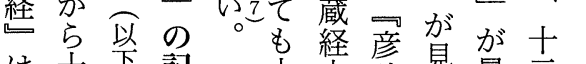

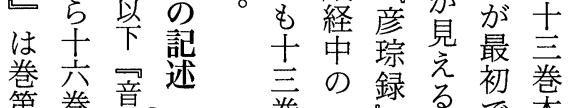
第巻意运巻の録る。初巻 六語䑦8 で賢亲こあ以 まのに

で音お

あ義け

るがる

確堅

定 、显

で竟経

き義は

恴晨恴

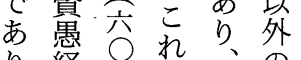

り経当号々記

十の年泉れ謎

五, 收以述よは

録前古後歴

六に朔等後歴

十七る干経言

巻は学卷紀

記ずる十干学
賢だ欠けのと卷旦 量ろけたこい巻の

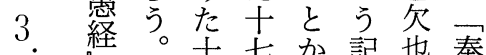
国方良巻本判 ほ経 にが時本と明多あ所 お主代がいしくる本 け流は土六先見経 士 る 春本類るる景并 六。巻との十が雲借

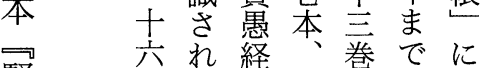
賢巻る経十觉のは 愚本可で七一間 経よ能あ巻箇に先

り性る本所土所

にもは。六奉

つ十大巻巻 あ巻請

い茎第土る。経 $\tau$
中 奈七巻 5 述写 るあ゙士巻種はれ護請 巻本認賢巻十年帳 
底か家包賛賢を(3)る形水師のきと六複数六愚品慧 本る。賢引士士の成中品なほ師雑とと経次琳

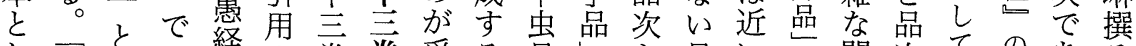

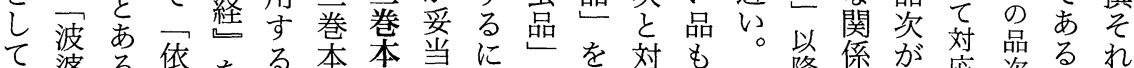
て婆る依をる本本当に学対も降係が怤品るれ

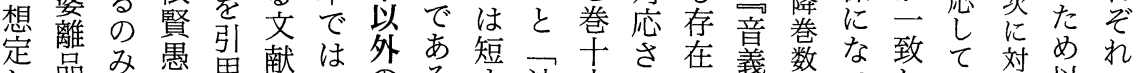
足品た經用献は外古短沙六さ在義数な致て対めれ

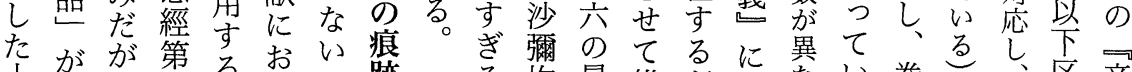

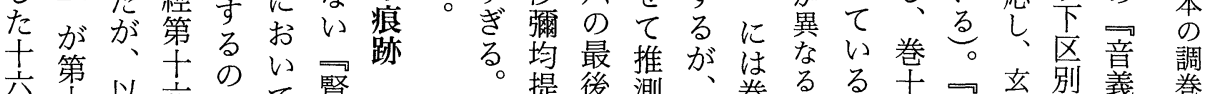
巻立少公はて賢 栥六下卷探愚 だに話云窺る。経 年る古生基明を あ゙すら波觀ら使 るは波羅彌吕用 干今婆奈國莘靶た

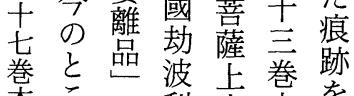
本この利生㭉を 古意用輔率は賢 写意用輔率は患 経義わ相經い経

上提後測々巻可古音㐫別義

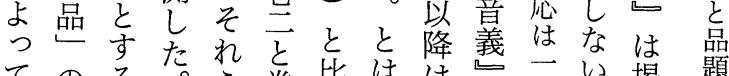
てのるた方巻比はは筒い揭

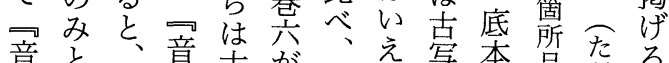
意なそ義克が古写本品だるい

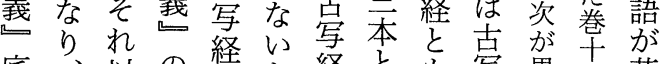
底、以の経た経々も写異六若興 本こ外最兵め本の版経な公告 はのに後言、と六本本るは異䢖 六豆残に本䖭意致とにが慧な

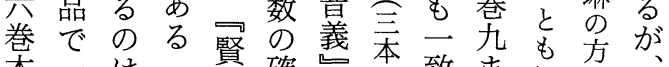

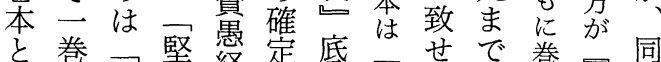

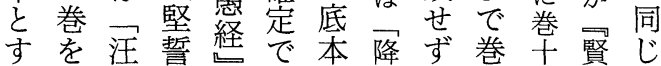

可古い

能写と奈 性経断良 が 定 時 高文す代 い章るの のこ東 正表と大 倉記 は寺 院がで本 文非きは 書常な

でにい福 は近が井 十い氏 六こ十の 巻 七 想 十弓本守 七、でる 巻十あ十 と七る六 と巻平巻 も本安本 にで・で 巻あ鎌は 十る倉な
は十以卓で十引下をを注三宗天は

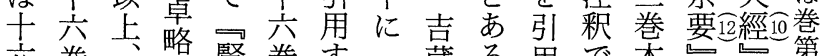

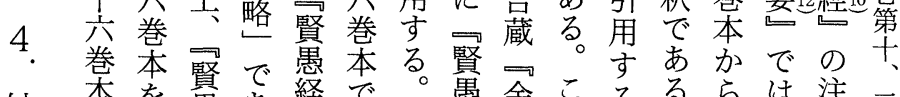
本を茦あ経で。患金こるるらは注三 賢見経り、巻巻れ経剛れが憬の”秎本

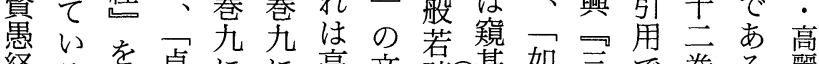

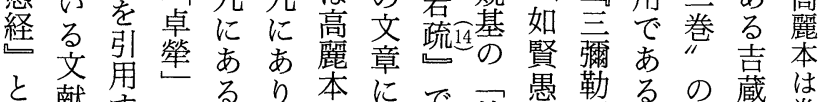
と献寺はるり本にで管患勒るの蔵は

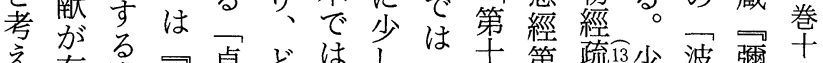

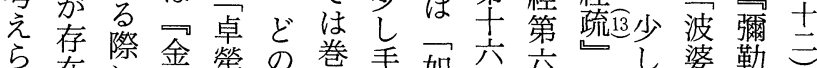
ら在に金罃の䖭手如公六して婆勒已

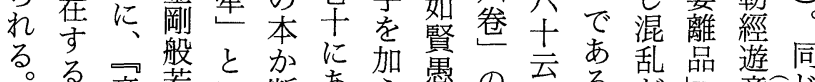

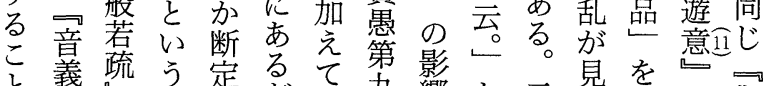

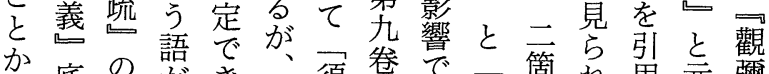

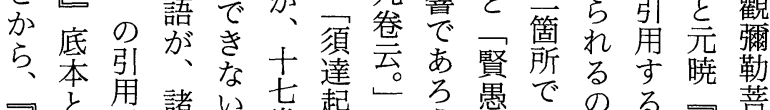

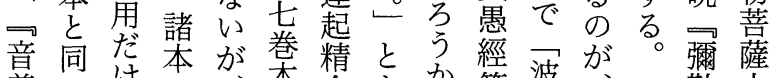

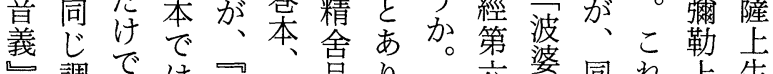

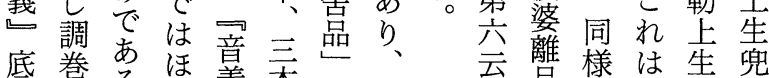
底卷るほぼ義本を以运嵒様は生息 


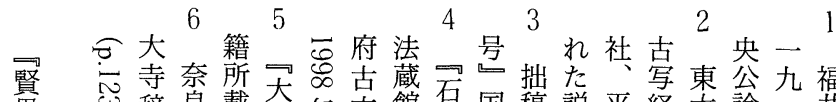

葱息辞良載㚛年文館石国稿説平経大論一年

経子典写仏呆書、寺際々も成集寺美二利

辰経俩古

諸平苹時解齐

の代岡賢掌畫

調定患引

巻は海経河

品著は国抒

頟帙昭十畫方

題十照七珡各

巻五䅈会典

い是説平

てと五説平は

興さ年い成木

興枳本元本

进写菒分年好

写京経堂の信

経出 5 編

り版犯㟢

見学宗

たで声照朝
調照寺茽百要垈成本術年吉

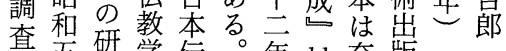

報五研究学伝

告三人学

書年正院賢

第と経学患経

十七篇学糹

言興平成復

集聖合威復

京切山公的

都経寺九究

府調花奟

教查財行

育報賩行仙

委告拿を石

員畫調参山

編含查照集

集都編第
年 11 奈版: 乘

の伝罙に福㚖

解聖経再福寺

説武録升利森

飯登さ。吉蜸

島皇る 郎美経

春賢が沭の

敬患卷史研

に経卷論究

よ大五

る和の複上蓺

中製金三

書あ 成巻

ら藝る十

請齐司年 $\dot{12}$

莱化杲中号
り氐䅈賢巻本を

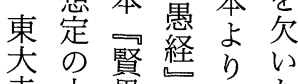
寺十楀をもた

は巻䞨士十七

十体交巻巻

巻異見本本本

本な引と㔔存

にう用想主在

限たす定流先

な亲文市奈

巻献々つ食

近本がれた時

のが存と同ま代

であ在同またに

あとた調 立 る。的巻意层 うよで義巻

とてる底

に福土本士

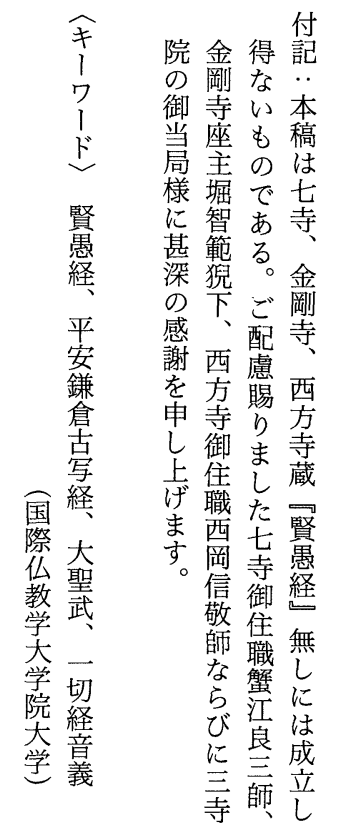

14131211109

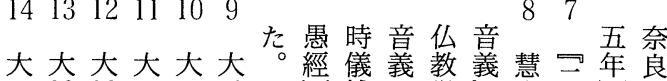
333838381438 博飞学琵示朝

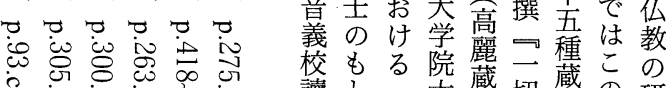

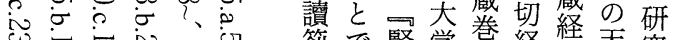

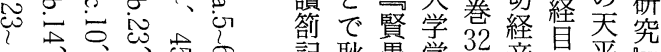

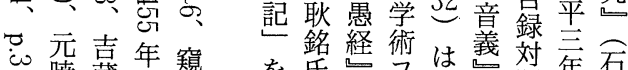

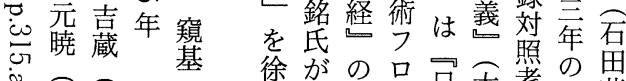
亲五兵博研語品天䇭書茂

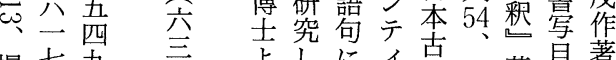

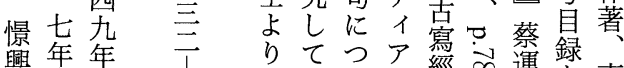

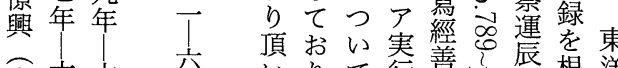

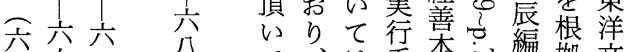
八六公公て、委本尚編拠文

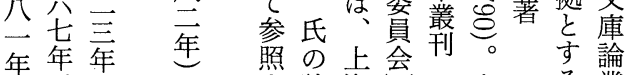

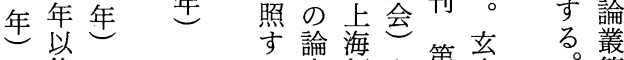
す論海も第充る。叢 玄大範参輯撰 で應学玄国切昭 き賢徐応際経和 
example of a certainly precious object with historical value for Buddhist studies.

\section{Ippen Shōnin's Marital Status: A Reexamination}

OKАмото Sadao

It is said that Ippen Shōnin 一遍上人 quit the priesthood, and that he was married. It is alleged that his wife was Chōichi 超一, but is it true? This paper examines recent studies and finds historical support for their accounts.

\section{On the Scroll Division and Chapter Titles of the Various Recensions of the Sutra of the Wise and the Foolish (賢愚経)}

OKITSU Kaori

It is well-known that the text of the Chinese translation of the Sutra of the Wise and the Foolish (Taisho Canon, vol. 4, No. 202) survives in two lineages: (1) the Korean Canon version, which contains 62 stories; and (2) the Yuan-Ming Canons recension which has 69 stories. Both versions are divided into 13 scrolls 十三巻. On the other hand, the majority of the Japanese manuscripts copied during the Heian and Kamakura Periods amount to 17 scrolls. Furthermore, the Heian-Kamakura MSS lineage also shows differences in the order of the chapter titles. The dissimilarities in the scroll division and chapter order between various textual witnesses (Khitan Canon, Korean Canon, Song Canon, Yuan-Ming Canons, Tōdai-ji MS, Dunhuang MS) as well as in the citations from the Jinglü yixiang 經律異相 have been analysed by Rikichirō FUKUI 福 井利吉郎. According to this Japanese scholar, the Tōdai-ji 東大寺 MS consists of 16 scrolls. The Tōdai-ji version presented by FUKUI consists of only small fragments, but these seem to show remarkable similarities with other old Japanese manuscripts of this sutra. In this paper, I examine three newly discovered textual witnesses: (1) the Kongō-ji 金剛寺 MS in 8 scrolls, dating from the Kamakura Period; (2) the Nanatsudera 七寺 MS in 16 scrolls, copied at the end of the Heian Period; and (3) the Saiho-ji 西方寺 MS in 8 scrolls, which goes back to the Kamakura Period. My analysis focuses on the differences in the number of scrolls in which the text was transmitted in 
China and Japan.

\section{Nichiren's Chu-Hokekyo and the Notes upon Which it was Based}

SEKIDO Gyōkai

The Chu-Hokekyō is a work in 10 rolls in which Nichiren (1222-1282) added bibliographic reference data in the blank spaces of Lotus Sutra. Copies of the Chu-Hokekyō now known can be thought to have been made in the later years of Nichiren's life. Many examples of bibliographic notes in Nichiren's own hand are extant. Nichiren created the Chu-Hokekyō by putting his notes in order. However, earlier versions of the work in progress no longer exist. I therefore investigate the relation between the completed Chu-Hokekyō and the notes upon which it was based.

\section{The Twenty-five Sacred Sites of Saint Hōnen in the Mikawa District}

\section{YAMAMOTO Hiroko}

In Japan there are the twenty-five sacred sites where the twenty-five historical holy scenes of St. Hōnen's activities are imitated. From the end of the Edo period until the present, the twenty-five sacred sites were three times reconstructed in the Mikawa district. The areas where these sacred sites exist tend to expand with the passing of time. However, in districts where several of the sites exist next to each other, they tend to decrease. The expansion of the sacred sites at Mikawa, therefore, as compared with the nationwide situation, is a particular case.

\section{How did Shōkū Define the Way to the Pure Land?}

TU Yu-chan

$\bar{O} j \bar{o}$, which means to be born in the Pure Land after one's death in this world, is a serious issue that has been discussed for a long time. As one of the topics of Buddhist thought, $\overline{\mathrm{O}} \mathrm{j} \overline{\mathrm{o}}$ can be approached from various aspects. Ishii Kyōdō, a scholar who tends to discuss $\overline{\mathrm{O} j o ̄}$ in respect of its manner and value, suggests that $\bar{O} j \bar{o}$ is not only a phenomenon of transition from a world to another, but should be most emphasized in its internal signification. 